\title{
Research
}

Paper

\section{Skeletal muscle relaxant effect of Chonemorpha macrophylla in experimental animals}

\author{
R.K. Roy ${ }^{\star}$, N.M. Ray ${ }^{\star \star}$, A.K. Das ${ }^{\star \star \star}$
}

* Department of Pharmacology,

N.R.S. Medical College, Kolkata - 700014

** Department of Pharmacology, U.C.M., Kolkata - 700004

*** Department of Pharmacology, R.G. Kar Medical College, Kolkata - 700004. India

Received: 20.11.2003

Revised: 14.9.2004

Accepted: 20.9.2004

Correspondence to:

Ranendra Kumar Roy

E-mail: rayon@vsnl.net rkroy_08@rediffmail.com

\begin{abstract}
Objective: To study the skeletal muscle relaxant property of Chonemorpha macrophylla (CM). Materials and Method: The skeletal muscle relaxant effect of the alcoholic extract of CM was studied on isolated frog rectus abdominis muscle, isolated rat phrenic nerve diaphragm muscle preparation and in intact young chicks. The parameter studied in the isolated muscle or isolated nerve muscle preparations was the extent of inhibition of acetylcholine or electrically-induced contraction of skeletal muscles. In intact chicks, the drug was administered i.v. in wing veins and the onset, duration and nature of paralysis were recorded. In all the experiments, the effect of the drug was compared with that of gallamine and succinylcholine.

Results: The alcoholic extract of CM reduced the acetylcholine-induced contraction of isolated frog rectus abdominis and electrically stimulated contractions of rat phrenic nerve diaphragm in a dose-dependent manner. In unanaesthetized chicks, it produced spastic type of paralysis with extension of the neck and limbs. The effects were similar to the effects of succinylcholine but different from those of gallamine.

Conclusion: The alcoholic extract of CM possesses skeletal muscle relaxant property. It produces depolarizing type of muscle paralysis similar to that produced by succinylcholine.
\end{abstract}

KEY WORDS: Nerve muscle preparation, spastic paralysis, gallamine, succinyl choline

\section{Introduction}

Chonemorpha macrophylla (CM) is a plant of the Apocyanaceae family. A preliminary report on the pharmacological effects of chloroform extract of a plant of the same family Ervatamia crispa revealed skeletal muscle relaxant effect on isolated frog rectus abdominis muscle preparation. ${ }^{[1]}$ There was no report of a similar study with CM. It was presumed that CM, being a member of same family, may have skeletal muscle relaxant property. There was already a report of the collection of a number of alkaloids of CM by the alcoholic extraction method. ${ }^{[2]}$ It was therefore considered to use the alcoholic extract for the present work.

\section{Materials and Methods}

\section{Preparation of the alcoholic extract of CM}

Powdered bark of CM (1.5 kg) was saxhleted with petroleum ether (B.P. $60-80{ }^{\circ} \mathrm{C}$ ) for $24 \mathrm{~h}$. The solvent was distilled off on water bath leaving a gummy residue $(17 \mathrm{~g})$. The defatted plant material was dried up in air and was percolated with ammonia and rectified spirit for 21 days. The solvent was removed under reduced pressure when a gummy residue $(10 \mathrm{~g})$ was obtained. This alcoholic extract was soluble in propylene glycol on little warming. A stock solution of $1 \mathrm{~g}$ of alcoholic extract of CM was prepared in $20 \mathrm{ml}$ of propylene glycol to make the concentration $50 \mathrm{mg} / \mathrm{ml}$ and was utilized for different experiments as mentioned below.

The effect of the drug was first studied on isolated frog rectus abdominis muscle by adopting standard procedure..$^{[3]} \mathrm{A}$ portion of frog rectus abdominis muscle was mounted in frog ringer solution in $5 \mathrm{ml}$ capacity organ bath maintained at $37+0.5{ }^{\circ} \mathrm{C}$ and aerated with oxygen. Each preparation was allowed to equilibrate for 30 min under the resting tension of $1 \mathrm{~g}$ to obtain stable basal condition.

Initially, a concentration of acetylcholine $\left(2.5 \times 10^{-7} \mathrm{M}\right)$ was identified which can produce sub maximal contraction (3.02 $\mathrm{cm})$ of the muscle. Contact time was 90 seconds. The effect of the vehicle propylene glycol $(0.1 \mathrm{ml})$ was noted by adding the vehicle in the bath and allowing to remain in contact with the muscle for 3 min followed by addition of the dose of acetylcholine. Any change in height was recorded. Similarly, the effects of the alcoholic extract of CM $(2 \mathrm{mg} / \mathrm{ml})$, succinylcholine $\left(1.25 \times 10^{-7} \mathrm{M}\right)$ and gallamine $\left(2.5 \times 10^{-7} \mathrm{M}\right)$ on acetylcholineinduced contractions were recorded. To know the effect of physostigmine $\left(3.3 \times 10^{-6} \mathrm{M}\right)$ and potassium chloride $\left(3 \times 10^{-1}\right.$ M) on the antiacetylcholine effect of the alcoholic extract of $\mathrm{CM}$, the respective agent was first administered into the bath $90 \mathrm{sec}$ before administration of the alcoholic extract of CM. Three minutes after administration of the test drug the preparation was then challenged with the same dose of acetylcholine. 
Table 1

Effects of different treatments on acetylcholine-induced contraction of isolated frog rectus abdominis muscle preparation

\begin{tabular}{|c|c|c|c|}
\hline \multirow[t]{2}{*}{$\begin{array}{l}\text { Drugs (concentration) } \\
\text { treatment }\end{array}$} & \multicolumn{2}{|c|}{$\begin{array}{l}\text { Height of contraction } \\
\text { (cm) mean }+S E M\end{array}$} & \multirow[t]{2}{*}{$\begin{array}{c}\% \\
\text { Change }\end{array}$} \\
\hline & Before & After & \\
\hline Propyleneglycol & $3.01 \pm 0.20$ & $3.01 \pm 0.20$ & \\
\hline $\mathrm{CM}(0.5 \mathrm{mg} / \mathrm{ml})$ & $3.02 \pm 0.27$ & $2.20 \pm 0.04^{*}$ & -28.60 \\
\hline $\mathrm{CM}(1.0 \mathrm{mg} / \mathrm{ml})$ & $3.00 \pm 0.28$ & $1.90 \pm 0.06^{\star *}$ & -34.50 \\
\hline $\mathrm{CM}(1.5 \mathrm{mg} / \mathrm{ml})$ & $3.00 \pm 0.10$ & $1.70 \pm 0.20^{\star \star *}$ & -43.30 \\
\hline $\mathrm{CM}(2.0 \mathrm{mg} / \mathrm{ml})$ & $3.06 \pm 0.02$ & $1.20 \pm 0.10^{\star \star \star}$ & -60.00 \\
\hline Succinylcholine $\left(1.25 \times 10^{-7} \mathrm{M}\right)$ & $1.90 \pm 0.04$ & $0.95 \pm 0.10^{* * *}$ & -50.00 \\
\hline Gallamine $\left(2.5 \times 10^{-7} \mathrm{M}\right)$ & $2.30 \pm 0.10$ & $1.40 \pm 0.03^{\star * *}$ & -39.10 \\
\hline \multicolumn{4}{|l|}{ Physostigmine $\left(3.3 \times 10^{-6} \mathrm{M}\right)+$} \\
\hline $\mathrm{CM}(2 \mathrm{mg} / \mathrm{ml})$ & $1.90 \pm 0.10$ & $0.70 \pm 0.10^{* * *}$ & -63.50 \\
\hline \multicolumn{4}{|l|}{ Physostigmine $\left(3.3 \times 10^{-6} \mathrm{M}\right)+$} \\
\hline Succinylcholine $\left(1.25 \times 10^{-7} \mathrm{M}\right)$ & $1.91 \pm 0.02$ & $0.80 \pm 0.10^{\star \star *}$ & -59.12 \\
\hline \multicolumn{4}{|l|}{ Physostigmine $\left(3.3 \times 10^{-6} \mathrm{M}\right)+$} \\
\hline Gallamine $\left(2.5 \times 10^{-7} \mathrm{M}\right)$ & $2.25 \pm 0.60$ & $2.30 \pm 0.10$ & +2.20 \\
\hline \multicolumn{4}{|l|}{ Potassium chloride $\left(3 \times 10^{-1} \mathrm{M}\right)+$} \\
\hline $\mathrm{CM}(2 \mathrm{mg} / \mathrm{ml})$ & $1.80 \pm 0.20$ & $0.70 \pm 0.10^{* * *}$ & -61.10 \\
\hline \multicolumn{4}{|l|}{ Potassium chloride $\left(3 \times 10^{-1} \mathrm{M}\right)+$} \\
\hline Succinylcholine $\left(1.25 \times 10^{-7} \mathrm{M}\right)$ & $1.70 \pm 0.20$ & $0.80 \pm 0.20^{* * *}$ & -52.90 \\
\hline \multicolumn{4}{|l|}{ Potassium chloride $\left(3 \times 10^{-1} \mathrm{M}\right)+$} \\
\hline Gallamine $\left(2.5 \times 10^{-7} \mathrm{M}\right)$ & $3.45 \pm 0.20$ & $3.50 \pm 0.10$ & +1.40 \\
\hline
\end{tabular}

$\mathrm{n}=6$ in each group; ${ }^{*} \mathrm{P}<0.05,{ }^{* \star} \mathrm{P}<0.01$ and ${ }^{* \star *} \mathrm{P}<0.001$ as compared to their corresponding values before treatment.

Similarly, the effects of physostigmine and potassium chloride on the antiacetylcholine effect of succinylcholine and gallamine were studied and compared with the test drug.

Then the effect of the alcoholic extract of CM on isolated rat phrenic nerve diaphragm preparation was carried out by the method of Bulbring. ${ }^{[4]}$ A triangular flap of diaphragm muscle was cut out with a portion of phrenic nerve attached to it from an albino rat weighing about $200 \mathrm{~g}$. The muscle was mounted in a large organ bath containing $40 \mathrm{ml}$ of Krebs solution maintained at $37.0 \pm 0.5{ }^{\circ} \mathrm{C}$ and aerated with oxygen. The preparation was allowed to equilibrate for 45 min under resting tension of 1-2 g. Contact time for each agent was $3 \mathrm{~min}$.

The preparation was stimulated indirectly $(2 \mathrm{~V})$ through the phrenic nerve with supramaximal square wave pulse of 0.5 milliseconds duration at $0.5 \mathrm{~Hz}$. The effects of the vehicle and the alcoholic extract of CM in the concentration of 50 and 100 $\mu \mathrm{g} / \mathrm{ml}$ on electrically stimulated contraction of rat diaphragm were recorded.

To know whether physostigmine could modify the inhibitory effect of the test drug on electrically stimulated contraction of diaphragm, a dose of physostigmine $\left(4 \times 10^{-5} \mathrm{M}\right)$ was added to the bath following the administration of the test drug $(100 \mu \mathrm{g} /$ $\mathrm{ml}$ ) and the effect was recorded for $5 \mathrm{~min}$.

The type of skeletal muscle relaxation produced by CM was studied in unanaesthetized intact young chicks by the method of Battle and Zaimis. ${ }^{[5]}$ The chicks weighing about $250 \mathrm{~g}$ were divided into 5 groups, each group containing 6 chicks. Each group of chicks received either propylene glycol $(0.1 \mathrm{ml})$, alcoholic extract of CM (10 and $20 \mathrm{mg} / \mathrm{kg}$ ), succinylcholine
Figure 1. A shows the responses of the graded doses of $\mathrm{CM}$ on acetylcholine-induced contraction. B and $C$ show the effect of physostigmine on the skeletal muscle relaxant effects of gallamine, CM and succinylcholine on isolated frog rectus abdominis muscle preparation. $D_{1}, D_{2}, D_{3}$ and $\mathrm{D}_{4}$ denote $0.5,1.0,1.5$ and $2.0 \mathrm{mg} / \mathrm{ml}$ of bath fluid of CM. - = acetylcholine $\left(2.75 \times 10^{-7} \mathrm{M}\right), \mathrm{g}=$ gallamine $\left(2.5 \times 10^{-7}\right.$ $\mathrm{M}), \mathrm{O}=$ physostigmine $\left(3.3 \times 10^{-6} \mathrm{M}\right)$ and $\mathrm{S}=$ succinylcholine $\left(1.25 \times 10^{-7} \mathrm{M}\right)$.

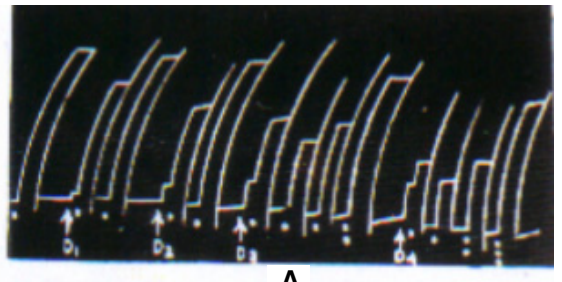
A

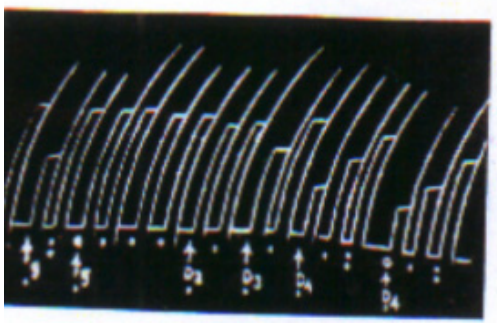

B

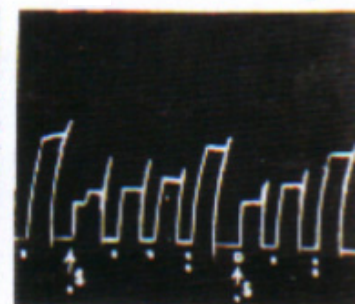

C
$(0.05 \mathrm{mg} / \mathrm{kg})$ or gallamine $(0.05 \mathrm{mg} / \mathrm{kg})$. All the drugs were administered i.v. through the wing vein of the chicks. The chicks of each group were observed carefully and any difference in the position of the limbs and neck were noted and compared.

\section{Statistical analysis}

Student's ' $t$ ' test was used to evaluate the difference in the height of contraction. The onset and duration of the paralysis of different drugs were compared using one-way analysis of variance (ANOVA) followed by Dunnett's test. A P value $<0.05$ was considered significant.

\section{Results}

Effect on isolated frog rectus abdominis muscle preparation

The alcoholic extract of CM antagonized acetylcholineinduced contraction in a concentration-dependent manner (Table 1 and Figure 1). Addition of physostigmine (3.3. $\times 10^{-6}$ M) further enhanced the inhibitory effect of the alcoholic extract of CM $(2 \mathrm{mg} / \mathrm{ml})$ by $63.5 \%$. The effect was comparable with the inhibitory effect (58.12\%) of the combination of physostigmine $\left(3.3 \times 10^{-6} \mathrm{M}\right)$ and succinylcholine $\left(1.25 \times 10^{-7}\right.$ M) on acetylcholine-induced contraction (Table 1 and Figure 1). Pretreatment with potassium chloride $\left(3 \times 10^{-1} \mathrm{M}\right)$ reversed the inhibitory effect of gallamine on acetylcholine-induced contraction of frog rectus abdominis muscle significantly but not that of the alcoholic extract of CM or succinylcholine (Table 1 and Figure 2).

Effects on isolated rat phrenic nerve diaphragm preparation

$\mathrm{CM}$ in a concentration of 50 and $100 \mu \mathrm{g} / \mathrm{ml}$ inhibited the contractile responses of nerve-stimulated rat phrenic nerve diaphragm muscle in a concentration-dependent manner (Table 2). Addition of physostigmine $\left(4 \times 10^{-5} \mathrm{M}\right)$ further augmented 
Figure 2.Effect of potassium chloride on the skeletal muscle relaxant effects of gallamine, CM (Panel A) and CM, Succinylcholine (Panel $B$ ) on isolated frog rectus abdominis muscle. $\cdot=$ acetylcholine $\left(2.75 \times 10^{-7} \mathrm{M}\right), 0=$ gallamine $\left(2.5 \times 10^{-7}\right.$ $\mathrm{M}),(\bullet)=$ potassium chloride $\left(3 \times 10^{-1} \mathrm{M}\right), \bullet=\mathrm{CM}(2 \mathrm{mg} / \mathrm{ml})$ and $+=$ succinylcholine $\left(1.25 \times 10^{-7} \mathrm{M}\right)$.
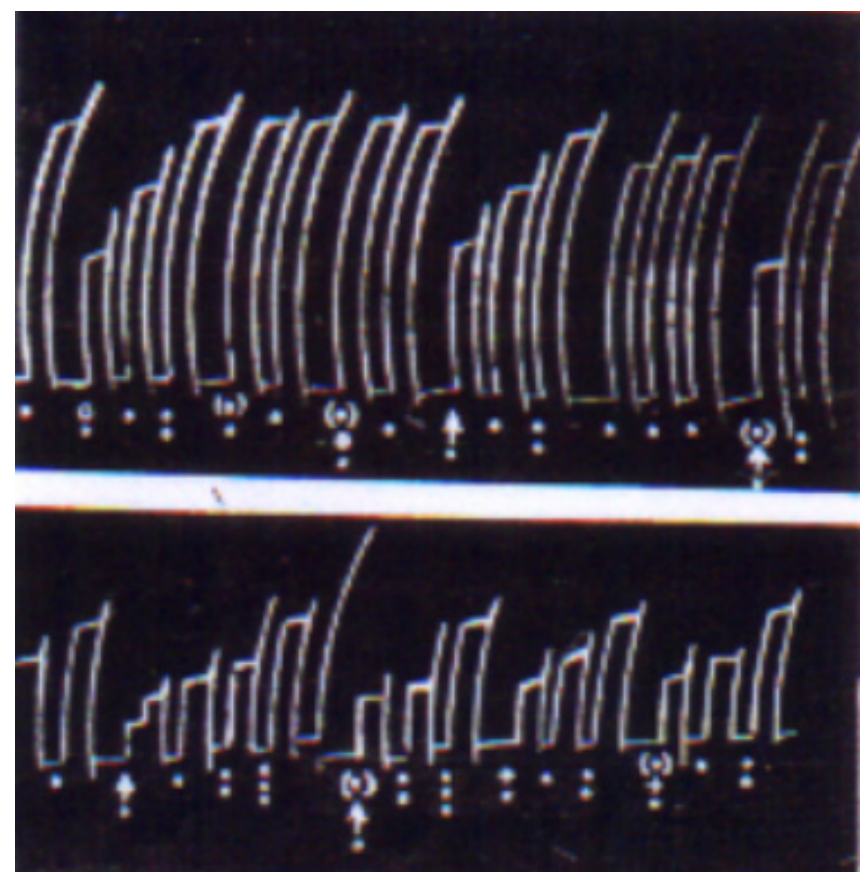

the inhibitory effect of CM (Table 2).

Effect on chick

Intravenous administration of CM in unanaesthetised chicks in a dose of 10 and $20 \mathrm{mg} / \mathrm{kg}$ body weight produced spastic paralysis with the extension of neck and limbs which was similar to that produced by $0.05 \mathrm{mg} / \mathrm{kg}$ dose of succinylcholine; however, the onset was delayed significantly and the duration of paralysis also was significantly shorter than that produced by succinylcholine (Table 3). On the contrary, gallamine produced a more rapid onset with longer duration of flaccid type of paralysis (Table 3).

\section{Table 2}

Effects of the alcoholic extract of $\mathrm{CM}$ and physostigmine on the contractile responses of electrically stimulated isolated rat phrenic nerve diaphragm

\begin{tabular}{lccc}
\hline $\begin{array}{l}\text { Drugs (conc.) } \\
\text { treatment }\end{array}$ & \multicolumn{2}{c}{$\begin{array}{c}\text { Height of contraction } \\
\text { (cm; mean } \pm \text { SEM) } \\
\text { Before }\end{array}$} & $\begin{array}{c}\text { \% of } \\
\text { inhibition }\end{array}$ \\
& $4.12 \pm 0.12$ & $4.12 \pm 0.20$ & -- \\
\hline Propylene glycol & $4.12 \pm 0.13$ & $2.20 \pm 0.04^{*}$ & 33.98 \\
CM $(50 \mu \mathrm{g} / \mathrm{ml})$ & $5.62 \pm 0.26$ & $0.61 \pm 0.05^{\star *}$ & 89.10 \\
CM $(100 \mu \mathrm{g} / \mathrm{ml})$ & & & \\
Physostigmine $\left(4 \times 10^{-5} \mathrm{M}\right)+$ & $4.12 \pm 0.10$ & $1.92 \pm 0.80^{\star *}$ & 53.30 \\
CM $(100 \mu \mathrm{g} / \mathrm{ml})$ & &
\end{tabular}

$\mathrm{n}=6$ in each group; ${ }^{*} \mathrm{P}<0.01$ and ${ }^{*}{ }^{*} \mathrm{P}<0.001$ as compared to their corresponding values before treatment.

\section{Discussion}

Studies on isolated skeletal muscle preparation of frog rectus abdominis muscle reveals that the alcoholic extract of CM can antagonize acetylcholine-induced contraction of the preparation. Pretreatment with potassium chloride reverses the muscle relaxant effect of gallamine but not that of the test drug or succinylcholine. The observation suggests that the alcoholic extract of CM possesses a depolarizing type of neuromuscular blocking action. This is further substantiated by the observation that pretreatment with physostigmine, which antagonizes the inhibitory effect of gallamine, enhances the inhibitory effect of both the alcoholic extract of CM and succinylcholine.

On isolated rat phrenic nerve diaphragm preparation, the alcoholic extract of CM reduces nerve stimulation-induced contraction of diaphragm, which is potentiated by the addition of physostigmine. The observation lends further support to the fact that CM possesses depolarizing type of neuromuscular blocking action.

The effect of CM on intact animals like young chicks further elucidates its mechanism of action. The drug produces extension of the neck and limbs like succinylcholine, a depolarizing blocker, whereas gallamine, a non-depolarizing blocker, produces flaccid type of paralysis.

Table 3

Effects of different treatment on the onset, duration and type of paralysis in unanaesthetized chicks

\begin{tabular}{|c|c|c|c|c|c|}
\hline $\begin{array}{l}\text { Drugs }(\mathrm{mg} / \mathrm{kg}) \\
\text { i.v. }\end{array}$ & $\begin{array}{c}\text { Onset of } \\
\text { paralysis } \\
\text { (min; mean+SEM) }\end{array}$ & $\begin{array}{c}\text { Duration of } \\
\text { paralysis } \\
\text { (in min; mean } \pm S E M \text { ) }\end{array}$ & $\begin{array}{c}\% \text { of } \\
\text { paralyzed chicks }\end{array}$ & Mortality if any & Nature of paralysis \\
\hline Gallamine $(0.05)$ & $12.5 \pm 2.0$ & $80.5 \pm 8.5$ & 100 & Nil & Flaccid \\
\hline Succinylcholine $(0.05)$ & $20.0 \pm 2.5$ & $60.0 \pm 5.0$ & 100 & Nil & Spastic \\
\hline $\mathrm{CM}(10.0)$ & $30.0 \pm 2.5^{\star \star}$ & $30.0 \pm 3.0^{* \star}$ & 89 & Nil & Spastic \\
\hline \multirow[t]{2}{*}{ ANOVA } & 2,15 & 2,15 & & & \\
\hline & 0.05 & 0.01 & & & \\
\hline
\end{tabular}

$\mathrm{n}=6$ in each group. ${ }^{*} \mathrm{P}<0.05$ and ${ }^{*} \mathrm{P}<0.001$ as compared to their corresponding value in the succinylcholine-treated group. 
Thus it is concluded that the alcoholic extract of CM possesses a depolarizing type of skeletal muscle relaxant property. In other words, the drug resembles succinylcholine with a slower onset and shorter duration of action.

\section{References}

1. Thirumalpad TK, Geetha VS, Kameswaram L. Chemical and pharmacological studies of the plant Ervatamia crispa (Syn. Tabernaemontana crispa Apocyanaceae). Curr Sci 1982;51:738-39.
2. Chatterjee A, Banerjee J. Occurrence of Funtumafrine-C in Chonemorpha macrophylla G. Don. (Chonemorpha fragrans Moon). Indian J Chem 1972;10; 1197.

3. Staff of the Department of Pharmacology, University of Edinburgh. Pharmacological experiments on isolated preparations. $2^{\text {nd }}$ edition. Edinburgh and London: E and S Livingstone; 1970.

4. Bulbring E. Observation on isolated rat-phrenic nerve diaphragm preparation of the rat. Br J Pharmac Chemother 1946;1:38.

5. Battle GA, Zaimis EJ. The action of decamethonium in birds. J Pharma Pharmacol 1949:1:991-92.

\title{
National Workshop on Basic Techniques in Molecular Biology \& Bio- informatics in Pharmacogenomics
}

\author{
(Jointly Organized by JIPMER, Pondicherry and VCRC, Pondicherry)
}

\section{July 27 to August 3, 2005}

\section{Objectives}

Pharmacogenomics Lab, Department of Pharmacology, JIPMER, Pondicherry 605006.

To provide training in basic molecular biology techniques that would be required in pharmacogenetic studies

To impart web-based training in basic concepts of bioinformatics

To impart theoretical knowledge on some of the recently developed molecular biology tools

To create a knowledge base of elementary medical genetics, statistical methods, etc. towards carrying out pharmacogenetic and related research

\section{Target Participants}

This workshop is intended for beginners in molecular biology and bioinformatics, with focus on 'pharmacogenomics'. A total of 20 participants will be admitted preferably post-graduate students and Faculty members of Departments of Pharmacology and Allied Sciences.

\section{Course Content}

The duration of the workshop is 8 days, and will include practical demonstrations and hands-on training in molecular biology techniques such as DNA extraction, quality check and quantification of DNA, the polymerase chain reaction - restriction fragment length polymorphism (PCR-RFLP), gel electrophoresis: horizontal and vertical, extraction of DNA from gel and purification of PCR products for sequencing and RT-PCR.

Bioinformatics will include locating the gene sequence of interest, identification of the PCR product, primer design, and selection of the restriction endonucleases and validation of the PCR method by sequencing.

Lectures will be held on the elements of medical genetics, organization of a molecular biology laboratory, microarray technology, DNA sequencing, high throughput screening for detection of mutations, elementary statistics for pharmacogenomics etc.

\section{Registration \& Accommodation}

The registration fee is Rs. 5000/-, which includes:

O Resource material on the various topics covered

O Hands - on training in bioinformatics

O Accommodation (dormitory/twin sharing will be arranged within the campus).
O Practical demonstrations

Lectures on current areas of interest in pharmacogenomics.

Breakfast, dinner and working lunch (Vegetarian food Only)

The registration form may be obtained by sending e-mail to: "Dr. C. Adithan, Organizing Secretary, National Workshop on Pharmacogenomics, Department of Pharmacology, JIPMER, Pondicherry 605006" E-mail: jipgene@yahoo.comTel: 0413-2272380 - 9 (10 lines) Ext. 3301. 